\title{
MANAJEMEN SUMBERDAYA KELUARGA: SUATU ANALISIS GENDER DALAM KEHIDUPAN KELUARGA NELAYAN DI PESISIR BONTANG KUALA, KALIMANTAN TIMUR
}

Family Resource Management, A Gender Analysis in Fisherman Family Life In Costal Area of Bontang Kuala, East Kalimantan

\author{
Qoriah Saleha ${ }^{1}$, Hartoyo ${ }^{2}$, Dwi Hastuti ${ }^{2}$
}

\begin{abstract}
The earning and work of fisherman families in Indonesia mostly depend on natural resources using only simple technology. The study was conducted in coastal area of Bontang Kuala, East Kalimantan Province in June and July 2002. One most densely populated sub district was chosen purposively. Result showed that the average income of its family per capita was higher than the average of Indonesian family. Family decision making in economic activities such as fishing investment, catchment's area selection, technology application were dominated by husband, while in religious, health and domestic activities except child education were dominated by wife. Higher the average contribution of wives to family income the higher the domination of wives in decision making in all activities that commonly dominated by husband. Time allocated for domestic, social, health, and economic activities of wife were higher than that of husband, while for income earning activities husbands' time was higher that of wives'. Correlation between variables showed that there was significant correlation between public decision making with public division of labor, and level of satisfaction of wives concerning public decision making but not with domestic decision making. Among domestic division of labor there were negative correlation with productive time and with leisure time of wives but not with public division of labor, and husbands' time allocation.
\end{abstract}

Keywords: family resource management, gender analysis, fisherman families

\section{PENDAHULUAN}

Potensi sumberdaya pesisir dan laut jika dimanfaatkan secara optimal dapat mensejahterakan masyarakat, terutama masyarakat pesisir. Masyarakat pesisir, terutama nelayan tradisional, pada kenyataannya termasuk pada masyarakat miskin dan tertinggal diantara kelompok masyarakat lainnya. Kondisi ini tercermin dari masih banyaknya kemiskinan yang dijumpai pada masyarakat nelayan dan kualitas sumberdaya manusia yang masih rendah (Dahuri et all, 2001; Ditjen Pesisir dan Pulau-pulau Kecil, 2001; Saruan, 2000). Pada umumnya di daerah-daerah nelayan, kaum istri ikut terlibat dalam kegiatan-kegiatan produktif, terutama yang berkaitan dengan kegitaan perikanan dan pengolahannya. Hal ini didukung oleh hasil studi yang dilakukan oleh Rizal (1985), memperlihatkan bahwa cukup banyak keterlibatan perempuan Bira, Sulawesi Selatan, sebagai penanggung jawab rumah tangga dalam aktivitas mencari nafkah dan bekerja keras ketika suami mereka berlayar. Disadari atau tidak keterlibatan istri ikut membantu dalam upaya meningkatkan pendapatan keluarga, namun masih kurang mendapat pengakuan bahwa istri cukup berperan besar baik di dalam rumah maupun diluar rumah. Dengan demikian, sudah saatnya keluarga memanfaatkan potensi yang ada dalam keluarga dan mengelola sumberdaya yang dimiliki dalam tatanan manajemen sumberdaya keluarga yang terencana dengan baik. Penelitian ini bertujuan untuk mengkaji dan menganalisis manajemen sumber daya keluarga yang dilakukan pada masyarakat nelayan berdasarkan pembagian peran antara suami dan istri. 


\section{METODE}

Waktu dan Lokasi Penelitian

Penelitian ini dilakukan mulai bulan Juni-Juli 2002 di Pesisir Desa Bontang Kuala, Kecamatan Bontang Utara, Kota Bontang-Kalimantan Timur. Penentuan lokasi ditingkat kecamatan dilakukan dengan metode purposive yaitu penentuan berdasarkan tujuan atau alasan tertentu (Singarimbun, 1989) yaitu berdasarkan potensi perikanan yang tinggi dan jumlah keluarga yang melakukan kegiatan dibidang perikanan. Adapun penentuan lokasi di tingkat desa berdasarkan potensi perikanan tangkap dan jumlah nelayan serta penyebaran penduduknya.

\section{Populasi dan Penentuan Sampel}

Populasi keluarga nelayan di lokasi penelitian adalah sebanyak 167 keluarga (Monografi Desa, 2000). Untuk penelitian ini diambil keluarga nelayan yang terdiri dari pasangan suami istri yang memiliki minimal satu orang anak berumur 12 tahun. Batas minimal umur anak ini ditentukan karena berhubungan dengan espektasi keluarga terhadap pendidikan anak. Berdasarkan kriteria tersebut terdapat populasi sebanyak 153 keluarga nelayan, kemudian dilakukan penarikan sampel secara acak sederhana sebanyak 60 keluarga nelayan dan yang menjadi contoh dalam penelitian ini adalah suami dan istri.

Jenis dan Cara Pengumpulan Data

Data yang dikumpulkan terdiri dari data primer yang diperoleh dari wawancara terstruktur dengan menggunakan daftar pertanyaan (kuesioner) dan wawancara mendalam (indepth interview) dengan tiga keluarga contoh serta observasi peran pada kegiatan sehari-hari suami dan istri untuk data yang berkaitan dengan pembagian kerja dan curahan waktu. Data sekunder diperoleh melalui dokumentasi dan kepustakaan dari publikasi atau laporan instansi terkait seperti Dinas Perikanan Kota Bontang dan Propinsi Kalimantan Timur, Kantor Kecamatan, Monografi Desa dan lainlain.

Pengolahan dan Analisis Data Metode analisis data yang digunakan adalah metode analisis deskiptif berbasis tabulasi dengan pendekatan kuantitatif dan kualitatif. Pengolahan data dilakukan dengan proses cleaning, coding, editing, data entry dan disajikan dalam bentuk deskripsi, tabulasi serta inferensia data kuantitatif atau statistik. Hubungan antara karakteristik sosial ekonomi dengan persepsi dan tugas berdasarkan gender dianalisis secara kuantitatif dengan pendekatan statistik uji Chi Square. Perbedaan pengambilan keputusan berdasarkan kontribusi pendapatan istri akan diuji dengan anova, sedangkan korelasi antara pengambilan keputusan, pembagian kerja, curahan waktu suami, curahan waktu istri dan tingkat kepuasan dianalisis dengan korelasi Spearman.

HASIL DAN PEMBAHASAN

Karakteristik Keluarga Contoh Kelompok Umur Contoh. Berdasarkan kelompok umur pada tabel 1, persentasi tertinggi (35\%) kelompok umur suami adalah antara 40-49 tahun, sedangkan persentasi tertinggi $(33.3 \%)$ terdapat pada kelompok umur istri $\leq 29$ tahun. Menurut Kusumosuwidho (1981), kelompok umur produktif mulai umur 15-64 tahun maka sebagian besar contoh suami (88.3\%) dan istri $(95 \%)$ berada pada kelompok usia produktif. 
Tabel 1. Sebaran Contoh Berdasarkan Kelompok Umur

\begin{tabular}{|c|c|c|c|c|}
\hline \multirow{2}{*}{$\begin{array}{c}\text { Kelompok } \\
\text { Umur }\end{array}$} & \multicolumn{2}{|c|}{ Suami } & \multicolumn{2}{|c|}{ Istri } \\
\cline { 2 - 5 } & $\mathbf{n}$ & $\mathbf{( \% )}$ & $\mathbf{n}$ & $\mathbf{( \% )}$ \\
\hline $25-29$ & 5 & 8.3 & 20 & 33.3 \\
\hline $30-39$ & 17 & 28.3 & 13 & 21.7 \\
\hline $40-49$ & 21 & 35.0 & 19 & 31.7 \\
\hline $50-59$ & 10 & 16.7 & 5 & 8.3 \\
\hline$\geq 60$ & 7 & 11.7 & 3 & 5.0 \\
\hline Jumlah & 60 & 100 & 60 & 100 \\
\hline
\end{tabular}

Rata-rata $=43,8 ; \mathrm{Sd}=11,4$

Tingkat Pendidikan. Pada umumnya, tingkat pendidikan formal yang ditempuh oleh mayoritas contoh adalah rendah. Sebagian besar contoh suami $(76.7 \%)$ dan contoh istri (85\%) berpendidikan hingga SD. Sebagian kecil contoh suami $(13.3 \%)$ dan contoh istri $(6.7 \%)$ berpendidikan hingga tingkat SLTP, sedangkan sisanya (10\% contoh suami dan $8.3 \%$ contoh istri) berpendidikan hingga SMA.

Tingkat Pendapatan Contoh. Pendapatan keluarga merupakan sejumlah hasil usaha yang diperoleh suami dan istri. Tingkat pendapatan dapat dilihat pada tabel 2, persentasi terbesar suami $(53.3 \%)$ berada pada tingkat pendapatan Rp 501.000 hingga Rp 1.000.000. Persentasi terbesar untuk tingkat pendapatan istri $(73.3 \%)$ berada pada kelompok tingkat pendapatan $\leq$ Rp 500.000,-. Tetapi terdapat pula beberapa kasus dimana pendapatan istri lebih tinggi dari suami.

Tabel 2. Sebaran Contoh Berdasarkan Tingkat Pendapatan

\begin{tabular}{|c|c|c|c|c|c|}
\hline $\begin{array}{c}\text { Pendapatan Suami } \\
\text { (Rp per bulan) } \\
(\mathbf{n = 6 0 )}\end{array}$ & \multicolumn{5}{|c|}{ Pendapatan Istri (Rp per bulan) $\mathbf{( n = 6 0 )}$} \\
\cline { 2 - 6 } & $\mathbf{5 0 0 . 0 0 0}$ & $\begin{array}{c}\mathbf{5 0 1 . 0 0 0 -} \\
\mathbf{1 . 0 0 0 . 0 0 0}\end{array}$ & $\begin{array}{c}\mathbf{1 . 0 0 1 . 0 0 0}- \\
\mathbf{1 . 5 0 0 . 0 0 0}\end{array}$ & $\mathbf{> 1 . 5 0 0 . 0 0 0}$ & Total \\
\hline$\leq 500.000$ & $3(5,0)$ & $4(6,7)$ & - & - & $7(10,0)$ \\
\hline $501.000-1.000 .000$ & $26(43,3)$ & $3(5,0)$ & $1(1,7)$ & $1(1,7)$ & $31(53,3)$ \\
\hline $1.001 .000-1.500 .000$ & $9(15,0)$ & $5(8,3)$ & - & $2(3,3)$ & $16(26,7)$ \\
\hline$>1.500 .000$ & $6(10,0)$ & - & - & - & $6(10,0)$ \\
\hline Total & $44(73,3)$ & $12(20,0)$ & $1(1,7)$ & $3(5,0)$ & $60(100)$ \\
\hline
\end{tabular}

Hasil perbandingan pendapatan suami dan istri terhadap pendapatan keluarga, diketahui sebagian besar $(78.7 \%)$ berasal dari pendapatan suami yaitu sebesar Rp 1.007.175. dan sisanya $(21.3 \%)$ berasal dari pendapatan istri (bekerja dan tidak bekerja) yaitu rata-rata sebesar Rp 336.925. Berbeda pada keluarga dengan istri pekerja, lebih dari separuh pendapatan yang berasal dari suami $(64.5 \%)$ rata-rata sebesar $\mathrm{Rp} 992.299$ dan sisanya $(35,5 \%)$ berasal dari pendapatan istri, rata-rata sebesar Rp 546.364.

Berdasarkan pendapatan perkapita, rata-rata pendapatan per kapitanya adalah $\mathrm{Rp} 290.369$ per bulan, dengan kisaran mulai $R p$ 62.500 hingga Rp 687.500 per bulan. Kisaran rata-rata tersebut tersebut bila dibandingkan dengan batas miskin penduduk di daerah pedesaan Kalimantan Timur, maka masih berada jauh di atas batas miskin daerah tersebut. Menurut laporan statistik Indonesia (2001), pendapatan perkapita daerah tersebut yaitu sebesar Rp 99.928 per bulan. Sebagian kecil contoh (8.3\%) memiliki pendapatan per kapita di bawah batas miskin. Dengan demikian, bila dilihat dari segi ekonomi, tingkat kesejahteraan penduduk Bontang Kuala mayoritas relatif cukup baik. Hal ini didukung oleh data hasil laporan tahunan Kantor Kepala Desa Bontang Kuala (2001). Berdasarkan kriteria dari BKKBN, lebih dari separuh (63.4\%) penduduk Bontang Kuala berada pada kelompok keluarga sejahtera II sampai keluarga sejahtera III plus dan seperempat penduduknya (25.3\%) berada pada kelompok keluarga sejahtera I kebawah.

Berdasarkan distribusi tingkat pendapatan per kapita, sebagian besar $(78.3 \%)$ keluarga contoh 
memiliki tingkat pendapatan Rp 146.100 hingga Rp 434.600 per kapita per bulan, dan sebagian kecil lainnya $(8.3 \%)$ merupakan keluarga contoh dengan tingkat pendapatan di bawah Rp 146.100 perkapita per bulan, dan $11.3 \%$ dengan tingkat pendapatan diatas Rp 434.600 perkapita per bulan. Jenis Pekerjaan Utama dan Pekerjaan Sampingan Contoh. Dukungan sumberdaya alam di daerah tersebut menjadikan hampir seluruh $(98.3 \%)$ pekerjaan utama suami sebagai nelayan dan sisanya $(1.7 \%)$ bergerak dalam pengelolaan budidaya rumput laut. Hampir separuh $(41.7 \%)$ contoh istri memiliki pekerjaan utama dalam pengolahan hasil laut (ikan asin, terasi, rumput laut kering, dan manisan rumput laut). Separuh contoh suami
(50\%) memiliki pekerjaan sampingan yang paling menonjol yaitu sebagai tukang kayu atau buruh bangunan. Hal ini disebabkan karena pekerjaan tersebut tidak memerlukan modal besar, namun penghasilan yang diterima cukup besar, dalam kisaran Rp 15.000 hingga Rp 50.000 per hari. Selain itu, upah tersebut dapat diterima harian setelah selesai kerja. Sementara itu, kurang dari separuh contoh istri $(37.5 \%)$ memiliki pekerjaan sampingan sebagai pedagang. Berdasarkan data yang diperoleh, lebih dari separuh istri nelayan $(61.7 \%)$ memiliki peran ganda yaitu sebagai ibu rumah tangga dan membantu mencari tambahan keluarga.

Tabel 3. Sebaran Contoh Berdasarkan Jenis Pekerjaan

\begin{tabular}{|c|c|c|c|c|}
\hline \multirow[t]{2}{*}{ Jenis Pekerjaan } & \multicolumn{2}{|c|}{ Suami $(n=60)$} & \multicolumn{2}{|c|}{ Istri $(n=60)$} \\
\hline & $\mathbf{n}$ & $(\%)$ & $\mathbf{n}$ & $(\%)$ \\
\hline \multicolumn{5}{|l|}{ 1. Pekerjaan Utama } \\
\hline - Nelayan & 59 & 98,3 & - & - \\
\hline - Budidaya Rumput Laut & 1 & 1,7 & - & - \\
\hline - Pengolah Hasil Laut & - & - & 25 & 41,7 \\
\hline - Pedagang & - & - & 12 & 20 \\
\hline - Tidak Bekerja & - & - & 23 & 38,3 \\
\hline Jumlah & 60 & 100 & 60 & 100 \\
\hline \multicolumn{5}{|l|}{ 2. Pekerjaan Sampingan } \\
\hline - Nekayan & 1 & 4,2 & - & - \\
\hline - Budidaya Rumput Laut & 3 & 12,5 & - & - \\
\hline - Pengolah Hasil Laut & - & - & 1 & 12,5 \\
\hline - Pedagang & 1 & 4,2 & 3 & 37,5 \\
\hline - Tukang Kayu/Buruh Bangunan & 12 & 50,0 & - & - \\
\hline - Tukang Jahit & - & - & 1 & 12,5 \\
\hline - Buruh Pengolah Hasil Laut & - & - & 1 & 12,5 \\
\hline - Buruh Tambak & 1 & 4,2 & - & - \\
\hline - Membuat Jaring/Alat Tangkap & 3 & 12,5 & 1 & 12,5 \\
\hline - Bengkel Ketinting & 1 & 4,2 & - & - \\
\hline - Pandai Besi & 1 & 4,2 & - & - \\
\hline - Menyewakan Perahu & 1 & 4,2 & - & - \\
\hline - Pembantu RumahTangga & - & - & 1 & 12,5 \\
\hline Jumlah & 24 & 100 & 8 & 100 \\
\hline
\end{tabular}

Kedudukan Contoh dalam Masyarakat. Sebagian kecil contoh suami $(28.3 \%)$ dan contoh istri $(8.3 \%)$ mendapat pengakuan sebagai tokoh masyarakat yang dianggap sebagai golongan tua yang berperan sebagai pengurus organisasi sosial dan kemasyarakatan, serta dianggap memiliki pengalaman dan pengetahuan lebih. Adapun yang berkedudukan sebagai masyarakat biasa yaitu yaitu sebagian besar suami $(71.7 \%)$ dan istri $(91.7 \%)$. Adapun kegiatan organisasi kemasyarakatan yang digeluti para suami antara lain seperti pengurus kelompok nelayan, 
pengurus mesjid dan pengurus organisasi pemuda desa, sedangkan kegiatan organisasi sosial kemasyarakatan yang digeluti para istri seperti pengurus pengajian, pengurus $\mathrm{PKK}$, pengurus kelompok arisan dan pengurus Posyandu.

Jumlah Anggota Keluarga. Berdasarkan kriteria jumlah anggota keluarga dari BKKBN dalam Pranadji (2001) tentang jumlah anggota keluarga. Keluarga contoh dalam penelitian ini dikelompokkan menjadi tiga kelompok yaitu 46.7\% (28 Kepala keluarga/KK) termasuk keluarga kecil, 43.3\% (26 Kepala Keluarga) termasuk keluarga sedang dan 10\% (6 Kepala Keluarga) termasuk keluarga besar dengan rata-rata jumlah anggota keluarga 5 orang dan $\mathrm{Sd}=1.8$.

Persepsi Tentang Gender dan Tugas Berdasarkan Gender yang dianut Keluarga Nelayan

Persepsi Tentang Gender dalam Keluarga Nelayan. Persepsi tentang gender dapat dilihat pada tabel 3, sebagian besar keluarga nelayan $(55 \%)$ memilih alternatif nomor 4 yang menyatakan bahwa suami-istri menyadari bahwa perbedaan jenis kelamin tidak harus dipertentangkan dalam menghidupi keluarga, tetapi justru bersifat saling mendukung dan melengkapi (Tabel 4).

Tabel 4. Sebaran Contoh Berdasarkan Alternatif Pilihan Persepsi tentang Gender

\begin{tabular}{|c|c|c|c|c|}
\hline \multirow[t]{2}{*}{ Alternatif Pilihan } & \multicolumn{2}{|c|}{ Suami } & \multicolumn{2}{|c|}{ Istri } \\
\hline & $\mathrm{n}$ & $(\%)$ & $\mathbf{n}$ & $(\%)$ \\
\hline $\begin{array}{l}\text { 1. Istri adalah mahkluk yang lebih lemah secara fisik danmental dari } \\
\text { suami sehingga wajar berada dalam posisi sosial yang lebih rendah } \\
\text { dalam keluarga. }\end{array}$ & 5 & 8,3 & 8 & 13,3 \\
\hline $\begin{array}{l}\text { 2. Istri tidak lebih lemah dari suami sehingga wajar bila berkedudukan } \\
\text { sejajar dalam mengatur keluarga. }\end{array}$ & 17 & 28,3 & 11 & 18,3 \\
\hline $\begin{array}{l}\text { 3. Istri mampu memberi kontribusi lebih dari suami dalam menghidupi } \\
\text { keluarga dan layak untuk mengelola keluarga. }\end{array}$ & 5 & 8,3 & 9 & 15,0 \\
\hline $\begin{array}{l}\text { 4. Istri dan suami menyadari bahwa perbedaan jenis kelamin tidak harus } \\
\text { dipertentangkan dalam menghidupi keluarga, tetapi justru bersufat } \\
\text { saling mendukung dan mekengkapi. }\end{array}$ & 33 & 55,0 & 32 & 53,3 \\
\hline Jumlah & 60 & 100 & 60 & 100 \\
\hline
\end{tabular}

Tugas Berdasarkan Gender dalam Keluarga Nelayan. Alternatif pilihan tugas berdasarkan gender dapat dilihat pada Tabel 5, pilihan terbanyak bagi suami-istri istri adalah pilihan nomor dua yang menyatakan bahwa tugas utama istri adalah mengurus rumah tangga, tetapi boleh membantu tugas suami dalam mencari nafkah keluarga sedangkan tanggung jawab mencari nafkah tetap tugas suami yaitu $51.7 \%$ dan $48.3 \%$ istri.

Tabel 5. Sebaran Contoh Berdasarkan Alternatif Pilihan Tugas berdasarkan Gender

\begin{tabular}{|l|l|l|l|l|}
\hline \multicolumn{1}{|c|}{ Alternatif Pilihan } & \multicolumn{2}{c|}{ Suami } & \multicolumn{2}{|c|}{ Istri } \\
\cline { 2 - 4 } & $\mathbf{n}$ & $\mathbf{( \% )}$ & $\mathbf{N}$ & $\mathbf{( \% )}$ \\
\hline $\begin{array}{l}\text { 1. Tugas istri adalah mengurus rumah tangga saja, sedangkan tugas suami } \\
\text { adalah mencari nafkah saja bagi keluarga. }\end{array}$ & 19 & 31,7 & 16 & 26,7 \\
\hline $\begin{array}{l}\text { 2. Tugas utama istri adalah mengurus rumah tangga, tetapi boleh } \\
\text { membantu tugas suami dalam mencari nafkah keluarga sedangkan } \\
\text { tanggung jawab mencari nafkah utama tetap tugas suami. }\end{array}$ & 31 & 51,7 & 29 & 48,3 \\
\hline $\begin{array}{l}\text { 3. Tugas suami tidak hanya mancari nafkah bagi kaluarga, tetapi juga harus } \\
\text { mau mambantu/berbagi tugas dengan istri dalam mengurus rumah } \\
\text { tangga. }\end{array}$ & 4 & 6,7 & 7 & 11,7 \\
\hline $\begin{array}{l}\text { 4. Tugas utama istri mengurus rumah tangga boleh digantikan orang lian } \\
\text { bila ia mampu mencari nafkah untuk keluarga dalam jumlah yang besar. }\end{array}$ & 3 & 5,0 & 4 & 6,7 \\
\hline $\begin{array}{l}\text { 5. Tugas utama istri mengurus rumah tangga dan tugas utama suami } \\
\text { mencari nafkah bagi keluarga boleh bertukar apabila secara ekonomi } \\
\text { memang menguntungkan. }\end{array}$ & 3 & 5,0 & 4 & 6,7 \\
\hline Jumlah & 60 & 100 & 60 & 100 \\
\hline
\end{tabular}


Pola Pengambilan Keputusan Dalam Keluarga

Pola pengambilan keputusan untuk aktivitas domestik dan aktivitas publik didasarkan pada tiga variasi pengambilan keputusan yaitu: (1) pengambilan keputusan yang didominasi oleh istri, (2) pengambilan keputusan oleh suami-istri senilai, (3) pengambilan keputusan yang didominasi oleh suami.

Pola Pengambilan Keputusan untuk Aktivitas Domestik. Pola pengambilan keputusan untuk aktivitas domestik yang terdapat pada masyarakat nelayan dapat dikatakan tidak didominasi oleh satu pihak saja. Hal ini dapat dilihat pada persentasi pengambilan keputusan aktivitas domestik. Dalam aspek pengambilan keputusan untuk penyediaan makanan, lebih didomninasi oleh istri. Misalnya, perencanaan menu $(88.3 \%)$, cara mengolah dan penyajian $(93.3 \%)$ dan pembagian ke anggota keluarga (95.0\%).

Pada aspek pendidikaan anak, keputusan lebih banyak dibuat oleh suami seperti jenis sekolah $(43.3 \%)$ dan tingkat pendidikan anak (55\%). Hal ini berkaitan dengan kemampuan keluarga dalam hal finansial untuk membiayai sekolah anak dan bila dikaitkan dengan pendapatan keluarga bahwa suami memberikan kontribusi yang lebih besar dalam pendapatan keluarga dibandingkan istri. Sejalan dengan temuan ini, Azizah (2001) juga mengemukakan bahwa pengambilan keputusan dalam pendidikan anak lebih banyak dibuat oleh suami pada masyarakat Makassar karena ia merasa bertanggung jawab sebagai pencari nafkah utama. Begitu pula pengambilan keputusan untuk kesehatan keluarga lebih banyak dibuat oleh suami, sepert memilih metode pengobatan $(43.3 \%)$ dan memilih tempat pengobatan (43.3\%).

Keputusan untuk menabung lebih banyak dibuat dominan oleh istri (55.0\%). Tetapi, keputusan berkaitan dengan memilih cara dan tempat menabung lebih banyak dibuat dominan oleh suami $(43,3 \%)$. Begitu pula keputusan perencanaan penggunaan tabungan dibuat dominan suami $(50.0 \%)$.

Pada pengambilan keputusan untuk aspek pemeliharaan rumah tangga menunjukkan bahwa istri dominan mengambil keputusan berkaitan dengan pengadaan perlengkapan utama $(45.0 \%)$ dan pembagian tugas pemeliharaan rumah tangga $(70.0 \%)$. Pengambilan keputusan yang dominan dibuat oleh suami adalah untuk pengadaan peralatan hiburan (45.0\%) dan perbaikkan bangunan rumah $(83.3 \%)$. Untuk aspek reproduksi keluarga, pengambilan keputusan lebih banyak dibuat bersama antara suami dan istri, seperti pada penetapan jumlah anak (45\%) dan penetapan jarak kelahiran (48.3\%). Sedangkan untuk pemilihan alat kontrasepsi keputusan lebih banyak dibuat dominan oleh istri (68.3\%). Hal ini berhubungan dengan siapa yang menggunakan alat kontrasepsi tersebut yang pada umumnya adalah istri.

Berdasarkan tersebut, diperoleh fenomena bahwa meskipun berkaitan dengan aktivitas domestik tetapi pola pengambilan keputusannya tidak identik menjadi bagian tanggung jawab dipihak istri saja, tetapi mulai menjadi tanggung jawab bersama meskipun salah satu pihak tetap lebih dominan.

\section{Pola Pengmbilan Keputusan untuk Aktivitas Publik \\ Pada pola pengambilan} keputusan untuk aktivitas publik yang dibagi dalam aspek ekonomi dan aspek sosial kemasyarakatan. Pola pengambilan keputusan disektor publik khususnya pada aspek ekonomi lebih banyak didominasi suami, tetapi pada aspek sosial kemasyarakatan pola pengambilan keputusannya tersebar lebih beragam. 
Untuk aspek ekonomi, pengambilan keputusan lebih banyak didominasi suami yaitu yang berhubungan dengan investasi atau modal usaha perikanan meliputi penetapan besarnya modal usaha (86.7\%), menambah atau mengurangi modal $(90.0 \%)$ dan keputusan untuk meminjam modal (88.3\%). Kemudian pengambilan keputusan dalam pengelolaan usaha perikanan tangkap, terdiri dari pemilihan jenis alat (98.3\%), perbaikan atau mengganti alat (93.3\%), penentuan daerah penangkapan dan penetapan waktu penangkapan $(100 \%)$. Begitu pula pada aktivitas pengolahan $(81.7 \%)$, menentukan skala usaha $(78.3 \%)$ dan memilih sistem pemasarannya $(76.7 \%)$. Tidak berbeda dengan pemasaran hasil perikanan tangkap yang meliputi penetapan harga jual $(81.7 \%)$, pemilihan sistem pemasaran $(78.3 \%)$ dan pemilihan sistem pembayaran $(76.7 \%)$.

Selanjutnya pengambilan keputusan untuk usaha non-perikanan (dari $n=27$ ) juga lebih banyak dibuat oleh suami yang meliputi pemilihan jenis usaha $(48.2 \%)$, penetapan skala usha $(51.9 \%)$ dan keputusan pelaksana usaha tersebut sebesar $(48.2 \%)$. Menurut mereka hal ini terjadi karena suami dianggap lebih mengerti mengenai hal-hal tersebut serta berkaitan pula dengan tanggung jawab yang besar tetap berada dipihak suami dan istri tidak merasa keberatan ataupun ada perasaan terpaksa bila keputusan tersebut dibuat sendiri suami.

Sementara itu pola pengambilan keputusan pada aspek sosial kemasyarakatan cukup bervariasi. Pengambilan keputusannya lebih banyak dibuat oleh istri adalah keputusan untuk kegiatan pengajian atau keagamaan (51.7\%) dan kegiatan PKK atau Posyandu (80.0\%). Sedangkan keputusan yang lebih banyak dibuat oleh suami adalah keputusan untuk kegiatan gotong royong $(83.3 \%)$ dan kegiatan perayaan lain (60.0\%). Untuk kegiatan selamatan, pengambilan keputusan dibuat bersama-sama (63.3\%). Hal ini karena berhubungan dengan kegiatan ini lebih sering dilakukan bersama.

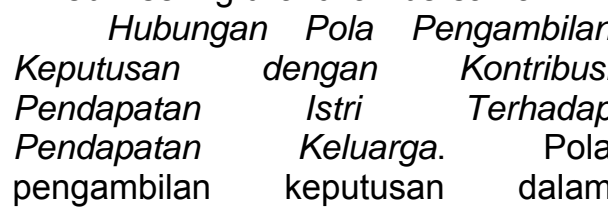
keluarga dimana istri mempunyai kontribusi besar terhadap pendapatan keluarga ternyata memiliki pola yang berbeda dengan keluarga dimana istri mempunyai kontribusi pendapatan yang kecil maupun tidak sama sekali. Fenomena ini ditemukan dalam proses pengambilan keputusan pada masyarakat di Bontang Kuala.

Pada sektor domestik, ditemukan perbedaan dominasi dalam proses pengambilan keputusan untuk aspek : pendidikan anak (memilih jenis sekolah, menentukan tingkat pendidikan), kesehatan keluarga (memilih metode pengobatan, memilih tempat pengbatan), tabungan keluarga (cara dan tempat menabung, perencanaan penggunaan) dan reproduksi (penetapan jumlah anak, penetapan jarak kelahiran) antara kasus keluarga dengan pendapatan istri lebih besar dan keluarga dengan pendapatan suami lebih besar. Sedangkan disektor publik, perbedaan dominasi terjadi pada aspek : pengelolaan usaha pengolahan hasil perikanan (memilih jenis usaha pengolahan, menentukan skala usaha, memilih sistem pemasaran) dan aspek usaha non-perikanan (pemilihan jenis usaha, penetapan skala usaha, pelaksana usaha).

Hal ini juga didukung oleh hasil uji Anova antara pengambilan keputusan (suami, suami istri, istri) dengan kontribusi pendapatan istri. Hasil uji menunjukkan bahwa untuk aktivitas domestik pengambilan keputusan yang lebih banyak dibuat oleh istri memiliki rata-rata pendapatan tertinggi yaitu Rp 507.900 dengan nilai $p=0.00$. Begitu pula dengan aktivitas 
publik, pengambilan keputusan yang lebih banyak dibuat oleh istri memiliki rata-rata pendapatan tertinggi yaitu $R p$ 571.750 dengan nilai $p=0.00$.

Pola Pembagian Kerja dalam keluarga Nelayan

Pola Pembagian Kerja Untuk

Aktivitas Domestik. Kegiatan yang berhubungan dengan sektor domestik khususnya dalam mengurus anak dan memelihara rumah tangga hampir semuanya kegiatan lebih banyak dilakukan oleh istri, seperti merawat anak sehari-hari $(73.3 \%)$, membersihkan rumah $(68.3 \%)$, mencuci dan menyetrika pakaian $(81.7 \%)$, menyediakan makanan $(98.3 \%)$, belanja kebutuhan sehari-hari $(98.3 \%)$ serta belanja peralatan rumah tangga (48.3\%).

Kecuali kegiatan mendampingi anak belajar, lebih banyak dilakukan oleh suami (38.3\%), karena ada anggapan pendidikan suami lebih memadai untuk mendukung kegiatan belajar anak, tetapi karena faktor keterbatasan waktu untuk menggantikan bapak dalam membimbing anak belajar yaitu $31.7 \%$. Aktivitas domestik yang sudah mulai banyak menyertakan peran suami bersama-sama dengan istri adalah merawat anak sakit $(78.3 \%)$, karena mereka sudah mulai menyadari tentang pentingnya kesehatan anggota keluarga sehingga harus ditangani secara serius bersamasama.

Hal yang cukup menarik adalah adanya peran suami membantu istri dalam merawat anak, membersihkan rumah, mencuci dan setrika pakaian, serta belanja kebutuhan sehari-hari. Suami ikut membantu pekerjaan rumah tangga pada saat belum pergi ke laut yaitu pagi hari atau malam hari. Kondisi ini terdapat pada keluargakeluarga yang memiliki anak yang masih kecil dan atau keluarga muda, sehingga pembagian kerja domestik dalam pertimbangan untuk membantu tugas istri. Sedangkan untuk keluarga yang memiliki anak yang cukup besar, tugas rumah tangga istri biasanya dibantu oleh anak mereka.

Hasil penelitian menunjukan bahwa, pada masyarakat tersebut secara implisit berlaku pola bimbingan kerja di sektor domestik adalah tanggung jawab istri, meskipun ditemukan juga pada beberapa kasus suami bersedia berbagi pekerja dengan istri dalam melakukan tugas rumah tangga.

Pola Pembagiaan Kerja Untuk Aktivitas Publik. Untuk aktivitas publik, pola pembagian kerja yang terjadi dalam masyarakat ini dapat dilihat dari pembagian kerja untuk aspek ekonomi dan aspek kegiatan sosial masyarakat. Pada aspek ekonomi yang menyangkut kegiatan usaha perikanan tangkap lebih banyak dikerjakan oleh suami seperti kegiatan menyiapkan alat $(86.7 \%)$, pelaksanaan oprasi penangkapan $(95.0 \%)$, dan perbaikan alat $(68.3 \%)$, tetapi pada kegiatan tersebut telihat pula keterlibatan istri. Hal ini terjadi karena beberapa keluarga yang kadang-kadang istri ikut membantu suami ke laut. Apabila istri ikut ke laut biasanya mereka telah mengerjakan tugas rumah tangga pada pagi harinya atau beberapa tugas rumah tangga tersebut dikerjakan oleh anggota keluarga lainya seperti anak. Sedangkan untuk kegiatan menyiapkan bekal ke laut lebih banyak dilakukan oleh istri $(88.3 \%)$.

Untuk kegiatan yang berkaitan dengan usaha pengolahan hasil perikanan lebih banyak dilakukan oleh bersama-sama antara suami dan istri seperti sortasi hasil tangkapan (ikan,udang, rumput laut) sebanyak $(50.0 \%$ dari $n=26)$ dan kegiatan pembersihan (ikan,udang, rumput laut) sebanyak $(42.3 \%$ dari $n=26)$. Kegiatan ini biasanya langsung dikerjakan para istri setelah para suami pulang dari menagkap ikan di laut sehingga dapat dilakukan bersama-sama sambil membersihkan alat tangkap seperti peralatan dan perahu. Sedangkan 
kegiatan proses pengolahan dan penjemuran lebih banyak dilakukan oleh istri $(65.4 \%)$. Karena biasanya penggaraman ikan asin dilakukan pada saat menjelang malam hari di saat para suami telah membersihkan diri setelah pulang dari laut atau pagi hari pada saat suami pergi ke laut. Sedangkan kegiatan menumbuk udang rebon, mencetak terasi, menjemur terasi, menjemur ikan asain dan menjemur rumput laut dilakukan pada saat siang hari dilakukan pada saat sela-sela waktu para istri melakukan rumah tangga mereka.

Kegiatan hasil pemasaran hasil tangkapan lebih banyak dilakukan oleh suami (51.7\%), biasanya karena mereka menjual hasil tangkapan langsung sebelum kembali ke rumah. Unuk menjual hasil olahan lebih banyak dilakukan oleh istri $(73.1 \%)$. Selain usaha perikanan tangkap dan pengolahan terhadap pula usaha lain yang masih berkaitan dengan usaha perikanan yaitu buruh usaha pengolahan $(n=1)$ hanya dikerjakan oleh istri, buruh tambak $(n=1)$ hanya dikerjakan oleh suami saja dan membuat jaring lebih banyak dikerjakan oleh suami $(66.7 \%$ dari $\mathrm{n}=3$ )

Pada aktivitas publik aspek ekonomi juga terdapat usaha nonperikanan. Adapun usaha ini yang hanya dilakukan oleh suami saja yaitu tukang kayu atau buruh bangunan $(n=12)$, usaha bengkel keliling/mesin perahu ( $n-1)$ dan usaha pandai besi $(n=1)$. Usaha berdagang banyak dilakukan oleh istri $(n=15$, sedangkan bekerja sebagai pembantu rumah tangga hanya dilakukan oleh istri $(n=1)$

Pola pembagian kerja pada aspek sosial kemasyarakatan, seperti kegiatan pengajiaan atau kegiatan keagamaan lebih banyak dihadiri oleh istri $(53,3 \%)$ dan kegiatan PKK atau posyandu sebanyak $100 \%$. Untuk kegiatan siosial kemasyarakatan seperti menghadiri undangan selamatan lebih banyak dilakukan oleh bersama-sama suami dan istri
(66.7\%), sedangkan untuk kegiatan gotong-royong lebih banyak dilakukan oleh suami $(78.3 \%)$.

Curahan Waktu Keria dalam Keluarga Nelayan

Pola curahan waktu kerja dalam keluarga nelayan dapat dilihat berdasarkan curahan waktu untuk kerja rumah tangga, kerja produktif, waktu luang, waktu pribadi dan waktu untuk kegiatan sosial. Pada tabel 5, secara umum istri mencurahkan 21.9 jam waktunya (91.1\%) untuk melakukan aktivitas domestik (kerja mengurus rumah tangga, waktu luang dan waktu pribadi). Curahan waktu untuk aktivitas domestik ini lebih banyak dibandingkan suami yang menghabiskan 13.5 jam (56.3\%).

Untuk kegiatan mengasuh anak, istri mencurahkan waktu lebih lama dibandingkan dengan suami yaitu 1.7 jam per hari. Tetapi disini terlihat pula keterlibatan suami dalam mengasuh anak, ini biasanya terjadi pada keluarga yang memiliki balita dimana suami meluangkan waktu untuk anaknya sebelum pergi ke laut atau setelah pulang dari laut. Kemudian untuk kegiatan pemeliharaan rumah tangga (mengambil air, membersihkan rumah, mencuci pakaian, memasak, belanja kebutuhan sehari-hari), curahan waktu istri lebih besar dibandingkan suami yaitu 4.2 jam per hari.

Begitu pula curahan waktu untuk perawatan diri (mandi, sholat, makan), santai (nonton TV, berbincang dengan keluarga, berbincang dengan tetangga dan olahraga), dan istirahat (tidur) lebih besar pada istri dibandingkan suami yaitu sebanyak masing-masing 1.6 jam per hari (perawatan diri), 6.1 jam per hari (waktu luang) dan 8.1 jam per hari (waktu istirahat). Sedangkan curahan waktu yang digunakan untuk membantu anak belajar, suami lebih besar curahan waktunya dibandingkan istri yaitu 2.7 jam per hari.

Untuk curahan waktu produktif dibidang perikanan dan non- 
perikanan. Pada kegiatan ekonomi dibidang perikanan, curahan waktu yang dikeluarkan oleh suami lebih besar dibandingkan istri yaitu 9.5 jam per hari. Mereka biasanya pergi kelaut pada pagi hari antara jam 06.30 sampai 09.00 dan mulai kembali ke rumah pada jam 15.00 sampai menjelang maghrib. Sedangkan untuk kegiatan ekonomi non-perikanan, curahan waktu istri lebih besar dibandingkan suami yaitu 0.8 jam per hari. Kondisi ini menunjukkan bahwa aktivitas mencari pendapatan sampingan di bidang non-perikanan lebih banyak dilakukan oleh istri.

berkaitan dengan sosial Kemudian untuk kegiatan yang kemasyarakatan, curahan waktu suami lebih besar dibandingkan istri meskipun selisih curahan waktunya relatif tidak besar (0.1 jam per hari). Hal ini menunjukkan, pada aktivitas sosial kemasyarakatan, masyarakat nelayan didaerah penelitian cukup membuka ruang publik untuk aktivitas sosial kemasyarakatan bagi istri.

Tabel 6. Sebaran Contoh Berdasarkan Rata-rata Curahan Waktu Kerja

\begin{tabular}{|l|c|c|c|c|}
\hline \multirow{2}{*}{ Kategori Waktu } & \multicolumn{2}{|c|}{ Suami } & \multicolumn{2}{c|}{ Istri } \\
\cline { 2 - 5 } & (jam/hari) & $\mathbf{( \% )}$ & (jam/hari) & (\%) \\
\hline 1. Waktu kerja rumah tangga (H) & & & & \\
\hline - Mengasuh anak & 0,4 & 1,6 & 1,7 & 7,0 \\
\hline - Pemeliharaan rumah tangga & 0,1 & 0,4 & 4,2 & 17,4 \\
\hline - Membantu anak belajar & 0,6 & 2,7 & 0,2 & 0,8 \\
\hline Sub Jumlah Waktu & $\mathbf{1 , 1}$ & $\mathbf{4 , 7}$ & $\mathbf{6 , 1}$ & $\mathbf{2 5 , 2}$ \\
\hline 2. Waktu kerja produktif (W) & & & & \\
\hline - Kegiatan perikanan & 9,5 & 39,6 & 0,9 & 3,6 \\
\hline - Kegiatan non perikanan & 0,4 & 1,6 & 0,8 & 3,2 \\
\hline Sub Jumlah Waktu & $\mathbf{9 , 9}$ & $\mathbf{4 1 , 2}$ & $\mathbf{1 , 7}$ & $\mathbf{6 , 8}$ \\
\hline 3. Waktu luang (L) & 3,5 & 14,7 & 6,1 & 25,5 \\
\hline Sub Jumlah Waktu & $\mathbf{3 , 5}$ & $\mathbf{1 4 , 7}$ & $\mathbf{6 , 1}$ & $\mathbf{2 5 , 5}$ \\
\hline 4. Waktu pribadi & & & & \\
\hline - Perawatan diri & 1,2 & 4,9 & 1,6 & 6,5 \\
\hline - Istirahat & $\mathbf{7 , 7}$ & 32,0 & 8,1 & 33,9 \\
\hline Sub Jumlah waktu & $\mathbf{8 , 9}$ & $\mathbf{3 6 , 9}$ & $\mathbf{9 , 7}$ & $\mathbf{4 0 , 4}$ \\
\hline 5. Sosial kemasyarakatan & 0,6 & 2,6 & 0,5 & 2,1 \\
\hline Sub Jumlah Waktu & $\mathbf{0 , 6}$ & $\mathbf{2 , 6}$ & $\mathbf{0 , 5}$ & $\mathbf{2 , 1}$ \\
\hline Total Waktu & $\mathbf{2 4}$ & 100 & $\mathbf{2 4}$ & 100 \\
\hline
\end{tabular}

Apabila curahan waktu antara istri yang bekerja produktif (usaha perikanan dan non-perikanan) dan istri tidak bekerja produktif (ibu rumah tangga) dibandingkan maka akan diperoleh hasil yang menunjukkan bahwa rata-rata curahan waktu yang digunakan istri yang bekerja produktif untuk berbagai aktivitas domestik maupun publik lebih kecil daripada curahan waktu yang digunakan istri yang tidak bekerja produktif, kecuali curahan waktu yang digunakan untuk kegiatan usaha perikanan dan nonperikanan (Tabel 6).
Hubungan Antara Karakterisitik dengan Persepsi Tentang Gender dan Tugas Berdasarkan Gender dalam Keluarga Nelayan.

Berdasarkan hasil uji ChiSquare yang dilakukan antara karakteristik (kedudukan dalam masyarakat, umur dan tingkat pendidikan) dengan persepsi tentang gender diperoleh hasil yang menunjukkan bahwa tidak terdapat hubungan diantara keduanya. Sedangkan antara karakteristik contoh (kedudukan dalam masyarakat, umur 
dan tingkat pendidikan) dengan tugas berdasarkan gender menunjukkan bahwa hanya pada tingkat pendidikan pada sitri yang terdapat hubungan dengan tugas berdasarkan gender (a $=0.005$, Chi-Square tab $=9.48$, istri : Chi-Square hit $=16.48, p=0.002$ ).

Fenomena tersebut disebabkan oleh sistem nilai yang diwariskan dan kemudian diadopsi oleh generasi adalah sistem nilai pariarki yang menempatkan laki-laki sebagai pihak yang lebih berhak dalam memimpin keluarga, lebih lanjut mereka menjelaskan bahwa perbedaan seksual alamiah membuat wanita secara fisik lebih lemah dan pada fase-fase tertentu (hamil, melahirkan dan menyusui) membuat mereka tergantung pada laki-laki.

Selain itu juga mereka termasuk masyarakat yang berpegang pada nilai-nilai agama Islam sehingga meskipun karakteristik mereka berbeda dan pemikiran mereka cukup terbuka terhadap pembagian peran antara suami dan istri tetapi hal tersebut tidak membuat perilaku mereka berubah dari kebiasaan masyarakat umumnya dalam melakukan kegiatan dalam keluarga.

Hubungan Antara Pengambilan Keputusan, Pembagian Keria, Curahan Waktu dan Tingkat Kepuasan Berdasarkan hasil uji korelasi Spearman yang dilakukan terhadap beberapa variabel (pengambilan keputusan, pembagian kerja, curahan waktu dan tingkat kepuasan, menunjukkan bahwa antara pengambilan keputusan domestik dengan variable lainnya tidak terdapat hubungan yang signifikan, begitu pula antara pengambilan keputusan publik $(r s=0.16, p=0.23)$. Antara pengambilan keputusan domestik dengan pembagian kerja dan pembagian kerja, curahan waktu (suami dan istri) dan kepuasan (suami dan istri) tidak terdapat hubungan yang signifikan.
Antara pengambilan keputusan publik dengan variabel lain, yang menunjukkan hubungan signifikan hanya antara pengambilan keputusan publik dengan pembagian kerja publik ( $\mathrm{rs}=0.41, \mathrm{p}=0.001)$, dan pengambilan keputusan publik dengan kepuasan public istri $(r s=0.33, p=$ 0.01). Hal ini terjadi karena pada pengambilan keputusan publik lebih banyak didominasi oleh suami sejalan dengan pembagian kerja publik juga lebih banyak. Didominasi oleh suami, dengan kata lain bahwa pihak yang mendominasi dalam mengambil keputusan publik maka ia akan lebih banyak pula terjun langsung pada pekerjaan disektor publik.

Demikian halnya dalam pengambilan keputusan publik dengan tingkat kepuasan istri di sektor publik yang artinya, apabila istri ikut serta dalam pengambilan keputusan disektor publik yang lebih banyak di dominasi oleh suami, maka istri kan merasa bahwa hal tersebut adalah suatu yang dapat memberikan kepuasan tersendiri, sedangkan bagi suami hal tersebut merupakan sesuatu yang biasa saja karena domain mereka memang lebih banyak di sektor publik.

Hasil uji kolerasi antara pembagian kerja domestik dengan variabel lainya menunjukan bahwa yang terdapat hubungan yang signifikan yaitu antara pembagiaan kerja domestic dengan waktu produksi istri ( $r s=0.35, p=0.007)$ dan diantara pembagiaan kerja domestik dengan waktu santai istri ( $r s=0.26, p=0.045)$. Hal tersebut berarti semakin besar pembagian kerja disektor domestik maka semakin bertambah waktu yang dapat digunakan istri untuk kegiatan produktif karena waktu domestik istri akan berkurang. Begitu pula dalam waktu pembagiaan kerja domestik dengan waktu santai istri menunjukan apabila pembagiaan kerja untuk sektor domestik semakin bertambah pula waktu santai istri 
Antara curahan waktu suami sendiri (waktu produksi, waktu domestik, waktu pribadi, waktu sosial dan waktu santai) yang terdapat hubungan signifikan yaitu antara waktu produksi suami dengan waktu pribadi suami ( $\mathrm{rs}=-0.24, \mathrm{p}=0.001$ ), waktu produksi suami dengan waktu sosial suami ( $r s=-0.65, p=0.000$ ), waktu produksi suami dengan waktu santai suami ( $r s=-51, p=0.000)$. Kemudiaan antara waktu domestik suami dengan waktu sosial suami ( $r s=$ -0.39, $p=0.002$ ), waktu domestik suami dengan waktu santai suami $r s=$ $-0.43, p==0.000$ ). Hal ini menunjukan bahwa dengan bertambah waktu produksi maka suami akan mengurangi atau mengorbankan pertama waktu sosial, waktu santai dan waktu pribadinya, sedangkan apabila suami menambah waktu domestiknya maka suami akan mengurangi waktu sosial dan waktu santainya.

Untuk curahan waktu istri sendiri waktu produksi, waktu domestik, waktu pribadi, waktu sosial dan waktu santai), pada gambar 4 yang terlihat hubungan signifikan yaitu antara waktu produksi istri dengan waktu domestik istri ( $r s=-0.52, p=0.000$ ) waktu produksi istri dengan waktu pribadi istri ( $r s=-0.51, p=0.000)$ waktu produksi istri dengan waktu sosial istri ( $\mathrm{rs}=$ $0.39, p=0.002$ ) dan waktu produksi istri dengan waktu santai istri ( $\mathrm{rs}=$ $0.36, p=0.004$ ) berdasarkan keempat hubungan di atas menunjukan bahwa bila istri menambah waktu untuk kegiatan produksi maka akan menyebabkan secara berurutan berkurang waktu untuk kegiatan domestik, waktu pribadi, waktu sosial dan waktu santainya. Selanjutnya, antara waktu domestik istri dengan waktu sosial istri ( $r s=-0.34, p=$ 0.008 ), antara waktu pribadi istri dengan waktu santai istri $(r s=-0.26, p$ $=0.042$ ) kemudiaan antara waktu sosial istri dengan waktu santai istri (rs $=-0.54, p=0.000$ ).
Antara curahan waktu suami dan curahan waktu istri, yang terdapat hubungan signifikan yaitu waktu produksi suami dengan waktu domestic istri ( $r s=0.46, p=0.000$ ) hal ini terjadi karena bagi suami yang lebih banyak menghabiskan waktu untuk kegiatan produksi akan semakin sedikit meluangkan waktu untuk kegiatan domestik, sehingga kegiatan domestik akan lebih banyak dikerjakan oleh istri. Hal ini sejalanh dengan kolerasi antara waktu produksi suami dengan waktu santai istri ( $r s=-0.48, p$ $=0.000$ ), yaitu dengan bertambahnya waktu produksi suami maka akan bertambah pula waktu domestik istri sehingga hal tersebut akan mengurangi waktu santai istri.

Kemudian antara waktu domestik suami dengan waktu pribadi istri ( $r s=0.60, p=0.000$ ) dan waktu domestik suami dengan waktu santai istri $(r s=0.35, p=0.006)$, menunjukan apabila suami menambah waktu domestinya maka waktu pribadi dan waktu santai istri akan bertambah karena waktu domestik menjadi berkurang dengan adanya bantuan suami. Begitu pula antara waktu sosial suami dengan waktu domestik istri (rs $=0.48, p=0.000$ ), waktu sosial suami dengan waktu pribadi istri ( $\mathrm{rs}=-0.38$, $p=0.003$ ) waktu sosial suami dengan waktu santai istri ( $r s=-0,29, p=$ 0,024 ). Selanjutnya antara waktu santai santai suami dengan waktu pribadi istri ( $r s=-0.40, p=0.001$ ) dan waktu santai suami dengan waktu santai istri ( $r s=0.47, p=0.000$ ).

Uji kolerasi antara tingkat kepuasan istri (kepuasan domestik, kepuasan publik) dan tingkat kepuasan istri (kepuasan domestic, kepuasan publik), cenderung terhadap hubungan yang signifikan yaitu antara kepuasan domestik suami dengan kepuasan domestik istri $(r s=0,59, p=$ 0,000 ), antara kepuasan domestik suami dengan kepuasan publik istri ( $r s=0.45, p=0.000$ ), antara kepuasan domestik istri dengan kepuasan publik suami ( $r s=0.32, p=0.012$ ), antara 
kepuasan domestik istri dengan kepuasan publik istri ( $r s=0.13, p=$ 0.017) dan antara kepuasan publik suami dengan kepuasan publik istri ( $r s=0.54, p=0.000)$, artinya apabila kepuasan suami pada kondisi sosial ekonomi baik domestik maupun publik bertambah maka kepuasan istri juga bertambah. Tetapi antara tingkat kepuasan baik suami maupun istri tidak terdapat hubungan dengan pengambilan keputusan, pembagian kerja dan curahan waktu, kecuali dengan pengambilan keputusan publik.

\section{SIMPULAN}

Penelitian ini menunjukkan adanya hubungan antara karakteristik (kedudukan dalam masyarakat, umur dan tingkat pendidikan) dengan persepsi dan pilihan tugas berdasarkan gender, kecuali variabel pendidikan istri yang terdapat hubungan dengan pilihan tugas berdasarkan gender. Hasil kolerasi antar beberapa variabel menunjukan bahwa terdapat hubungan yang positif antara pengambilan keputusan publik dengan pengambilan keputusan publik dengan kepuasan publik istri, tetapi tidak pada pengambilan kepustusan domestik. Antara pembagiaan kerja domestik terhadap hubungan yang negatif dengan waktu produksi istri dan waktu santai istri, tetapi tidak pada pembagian kerja publik dan curahan waktu suami. Terdapat hubungan pula antara curahan waktu suami dengan curahan waktu istri, antara kepuasan domestic dengan kepuasan domestik istri, antara kepuasan publik suami dengan kepuasan publik istri, antara kepuasan domestik suami dengan kepuasan domestik istri.

\section{DAFTAR PUSTAKA}

Dahuri, R Rais J., Ginting, S., P dan Sitepu. 2001. Pengelolah Sumberdaya Wilayah Pesisir dan Lautan Secara Terpadu. Jakarta : Pradya Paramita.
Dahuri, R. 2002. Membangun Kembali Perekonomian Indonesia Melalui Sektor Perikanan dan Kelautan. Jakarta : Lembaga Informasi dan Studi Pembangunan Indonesia.

Damanhuri, D. $2000 . \quad$ Pradoks Pembangunan Ekonomi Indonesia dan Perspektif Pemberdayaan Ekonomi Rakyat di sector Pertaniaan dan Perikanan. Bogor : Jurusan sosial Ekonomi Perikanan IPB.

Direktorat Jendral Pesisir dan Pulau-Pulau Kecil. 2001. Pedoman Umum Pelaksanaan Pemberdayaan Perempuaan Nelayan. Jakarta : Departemen Kelautan dan Perikanan.

Kusumosuwidho, S. 1981. Dasar-dasar Demografi. Jakarta. Lembaga Demografi Fakultas Ekonomi UI.

Rizal, J.1985. Kehidupan Wanita Bira: Studi Sosiologi tentang Pola Perikelakuaan Wanita Masyarakat Pelayar, dalam Mukhlis dan Kathryn, R. (editor). Masyarakat Pantai. Ujung Pandang. Lembaga Penerbit Unhas.

Singarimbun, M. 1989. Metode Penelitian Survei. Jakarta : LP3ES.

1 Departemen Gizi Masyarakat dan

Sumberdaya Keluarga, IPB

2 Departemen IImu Keluarga dan Konsumen, IPB

Alamat Korespondensi: Hartoyo

Departemen IImu Keluarga dan Konsumen, Fakultas Ekologi Manusia IPB JI. Lingkar Kampus IPB Darmaga 16680

Telp. (0251) 8628303, Fax. (0251) 8627432 